\title{
Article
}

\section{Iron-based binary metal-organic framework nanorods as an efficient catalyst for the oxygen evolution reaction}

\author{
Chuchu Wu ${ }^{a, b, c}$, Xiaoming Zhang a,b, Huanqiao Li ${ }^{\text {a,b }}$, Zhangxun Xia ${ }^{\text {a,b }}$, Shansheng Yu d, Suli Wang a,b,*, \\ Gongquan Sun a,b,\# \\ a Division of Fuel Cells and Battery, Dalian National Laboratory for Clean Energy, Dalian Institute of Chemical Physics, Chinese Academy of Sciences, \\ Dalian 116023, Liaoning, China \\ b Key Laboratory of Fuel Cells \& Hybrid Power Sources, Dalian Institute of Chemical Physics, Chinese Academy of Sciences, Dalian 116023, Liaoning, \\ China \\ c University of Chinese Academy of Sciences, Beijing 100049, China \\ d Department of Materials Science, Jilin University, Changchun 130012, Jilin, China
}

\section{A R T I C L E I N F O}

\section{Article history:}

Received 17 May 2020

Accepted 23 June 2020

Available online 5 September 2020

\section{Keywords:}

Oxygen evolution reaction

Metal-organic frameworks

Electrocatalysis

Electronic coupling effect

Water oxidation

\begin{abstract}
A B S T R A C T
First-row transition metal compounds have been widely explored as oxygen evolution reaction (OER) electrocatalysts due to their impressive performance in this application. However, the activity trends of these electrocatalysts remain elusive due to the effect of inevitable iron impurities in alkaline electrolytes on the OER; the inhomogeneous structure of iron-based (oxy)hydroxides further complicates this situation. Bimetallic metal-organic frameworks (MOFs) have the advantages of well-defined and uniform atomic structures and the tunable coordination environments, allowing the structure-activity relationships of bimetallic sites to be precisely explored. Therefore, we prepared a series of iron-based bimetallic MOFs (denoted as $\mathrm{Fe}_{2} \mathrm{M}-\mathrm{MIL}-88 \mathrm{~B}, \mathrm{M}=\mathrm{Mn}$, Co, or Ni) and systematically compared their electrocatalytic performance in the OER in this work. All the bimetallic MOFs exhibited higher OER activity than their monometallic iron-based counterpart, with their activity following the order FeNi > FeCo > FeMn. In an alkaline electrolyte, $\mathrm{Fe}_{2} \mathrm{Ni}$-MIL-88B showed the lowest overpotential to achieve a current density of $10 \mathrm{~mA} \mathrm{~cm}^{-2}(307 \mathrm{mV})$ and the smallest Tafel slope (38 mV dec $^{-1}$ ). The experimental and calculated results demonstrated that iron and nickel exhibited the strongest coupling effect in the series, leading to modification of the electronic structure, which is crucial for tuning the electrocatalytic activity.
\end{abstract}

(C) 2021, Dalian Institute of Chemical Physics, Chinese Academy of Sciences. Published by Elsevier B.V. All rights reserved.

\section{Introduction}

Hydrogen is a clean and flexible fuel for future energy applications, and can be produced via electrochemical water splitting process in conjunction with renewable but intermit- tent energy sources, such as solar or wind power. However, the oxygen evolution reaction (OER) on the anode is a complex four-electron process that involves $\mathrm{O}-\mathrm{H}$ bond breakage and $\mathrm{O}-\mathrm{O}$ bond formation, and therefore, a high overpotential is required to drive the anode reaction [1]. Thus, the development

\footnotetext{
* Corresponding author. Tel/Fax: +86-411-84762570; E-mail: suliwang@dicp.ac.cn

\# Corresponding author. Tel/Fax: +86-411-84379063; E-mail: gqsun@dicp.ac.cn

This work was supported by the Strategic Priority Research Program of the Chinese Academy of Sciences (XDA21090300), the National Natural Science Foundation of China (91834301) and DICP Grant (ZZBS201705).

DOI: 10.1016/S1872-2067(20)63686-5 | http://www.sciencedirect.com/science/journal/18722067 | Chin. J. Catal., Vol. 42, No. 4, April 2021
} 
of efficient, stable, and economical OER electrocatalysts to reduce the overpotential and energy losses of the anode reaction would be highly desirable.

Recent research in alkaline electrolytes has mainly focused on the electrocatalytic performance and underlying mechanism of OER electrocatalysts based on first-row transition metal compounds, especially oxides, layered double hydroxides, chalcogenides, phosphides, and nitrides based on $\mathrm{Mn}, \mathrm{Fe}, \mathrm{Co}$, and Ni [2-15]. Among these non-precious transition metal electrocatalysts, iron-based materials are noteworthy in two aspects. Firstly, monometallic iron-based compounds are generally considered to possess inferior electrocatalytic activity for the OER. For example, early work reported that the OER activity of transition metal oxides followed the order $\mathrm{RuO}_{2}>\mathrm{IrO}_{2}>$ $\mathrm{MnO}_{2}>\mathrm{NiO}>\mathrm{Co}_{3} \mathrm{O}_{4}>>\mathrm{Fe}_{3} \mathrm{O}_{4}$; this trend was explained in terms of the enthalpy of the reactions $\mathrm{MO}_{\mathrm{x}}+1 / 2 \mathrm{O}_{2} \rightarrow \mathrm{MO}_{\mathrm{x}+1}$ and the related trend in the $\mathrm{M}-\mathrm{O}$ bond strength $[16,17]$. A comparative study of nickel, cobalt, and iron oxide electrodes in $1 \mathrm{M}$ $\mathrm{NaOH}$ also showed that iron electrodes display the poorest OER performance [18]. Subbaraman et al. reported that the OER activity of well-characterized metal (oxy)hydroxide films on a $\mathrm{Pt}$ (111) surface followed the trend $\mathrm{Ni}>\mathrm{Co}>\mathrm{Fe}>\mathrm{Mn}$ [5]. Additionally, density functional theory (DFT) calculations conducted by Calle-Vallejo et al. [19] revealed that the OER activity of FeO is comparable to that of $\mathrm{CoO}$, but much poorer than that of $\mathrm{NiO}$. However, research by Corrigan [20] and others has shown that alkaline electrolytes inevitably contain iron impurities, which will be incorporated into non-iron catalysts, particularly nickel and cobalt-based materials, and significantly affect their OER performance. Since many early researchers did not recognize the presence and potential influence of the iron impurities, the activity trends discussed above may be inaccurate. Utilizing high-purity alkaline electrolytes, Boettcher et al. reported the revised activity trend $\mathrm{FeO}_{x} \mathrm{H}_{y}>\mathrm{CoO}_{x} \mathrm{H}_{y}>\mathrm{NiO}_{x} \mathrm{H}_{y}>\mathrm{MnO}_{x} \mathrm{H}_{y}$ in an alkaline electrolyte; they explained that the instability and insulating properties of iron-based (oxy)hydroxide mask its OER activity $[4,21,22]$. Based on the above discussion, iron species are unavoidable in alkaline electrolytes, and monometallic iron catalyst exhibit unsatisfactory OER catalytic activity. Hence, the development of bimetallic iron-based materials and the exploration of the underlying factors that regulate their OER activity is of great theoretical and practical significance.

Compared to monometallic systems, binary catalysts often exhibit enhanced catalytic performance. This enhancement is usually attributed to synergetic effects, which are defined as cooperation between different components and/or active sites in a catalyst that results in significantly enhanced catalytic performance relative to the sum of the performance of the individual components [23]. Unfortunately, the synthesis of bimetal oxides and (oxy)hydroxides based on iron requires significant effort. Taking NiFe (oxy)hydroxides as an example, Bell et al. revealed that $\mathrm{Fe}^{3+}$ shows limited solubility in nickel hydroxides and that increasing the iron concentrations above $50 \%$ leads to the appearance of a mixture of $\mathrm{FeOOH}$ and $\mathrm{Fe}_{2} \mathrm{O}_{3}[24,25]$. The resulting heterogeneity in the surface composition and structure complicates the evaluation of the OER performance of the catalysts. Recently, metal-organic frameworks (MOFs) have received great attention for their potential as (electro)catalysts [26-33], which originates from the well-defined microstructures that are formed by the coordination of organic ligands and metal-ion nodes. Among the various MOFs, iron-based MILs (named for the Materials Institute Lavoisier) show excellent stability due to the strong bonds between their trivalent metal ions and oxygen-anion-terminated linkers [34-36]. More interestingly, iron-based MILs show structural flexibility. One of the metal atoms in the trinuclear iron-cluster can be replaced by an atom of a second metal to produce $\mathrm{Fe}_{2} \mathrm{M}$ cluster nodes that resemble bimetallic electrocatalysts [37]. Therefore, based on their well-defined and uniform microstructures and adjustable coordination environments, iron-based bimetallic MILs show promise for the investigation of the OER electrocatalytic performance of bimetallic catalysts.

Herein, we focused on a series of bimetallic MOFs with MIL-88B structure ( $\mathrm{Fe}_{2} \mathrm{M}-\mathrm{MIL}-88 \mathrm{~B}, \mathrm{M}=\mathrm{Mn}, \mathrm{Fe}, \mathrm{Co}$, or $\mathrm{Ni}$; the abbreviations of $\mathrm{Fe}_{2} \mathrm{Mn}, \mathrm{Fe}, \mathrm{Fe}_{2} \mathrm{Co}$, and $\mathrm{Fe}_{2} \mathrm{Ni}$ are also used in this work for brevity) and investigated their electrocatalytic performance for the OER in alkaline electrolyte, as shown in Scheme 1. Compared with the monometallic Fe-MIL-88B, the incorporation of $\mathrm{Mn}, \mathrm{Co}$, and $\mathrm{Ni}$ enhance the catalytic activity. $\mathrm{Fe}_{2}$ Ni-MIL-88B clearly outperforms the other bimetallic MOFs, exhibiting a low overpotential of $307 \mathrm{mV}$ to achieve $10 \mathrm{~mA} \mathrm{~cm}-2$ and a small Tafel slope of $38 \mathrm{mV} \mathrm{dec}-1$. Further investigation demonstrated that introducing a second metal could induce a coupling effect between the different metal sites and modify their electronic structure, thereby expediting the OER process.

\section{Experimental}

\subsection{Synthesis of materials}

All reagents and solvents were obtained from commercial sources and used directly without further purification.

The Fe-MIL-88B framework was prepared according a previous reported method with slight modifications [38]. Briefly, $\mathrm{FeCl}_{3} \cdot 6 \mathrm{H}_{2} \mathrm{O}(0.90 \mathrm{mmol})$ and terephthalic acid $(1.0 \mathrm{mmol})$ were

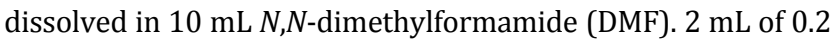
$\mathrm{M} \mathrm{NaOH}$ was quickly added to the above homogeneous solution, and the resulting mixture was stirred constantly for $1 \mathrm{~h}$. The mixture was then transferred into a Teflon-lined autoclave $(40 \mathrm{~mL})$ and heated without agitation at $100^{\circ} \mathrm{C}$ for $15 \mathrm{~h}$. Sub-

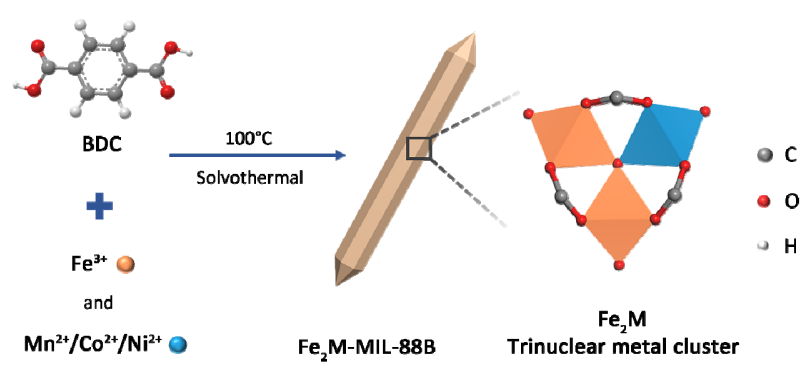

Scheme 1. Scheme of the preparation and structure of $\mathrm{Fe}_{2} \mathrm{M}-\mathrm{MIL}-88 \mathrm{~B}$ (Orange, blue, gray, red, and white spheres represent Fe, M, C, O, and H atoms, respectively). 
sequently, the products were centrifuged, washed sequentially with DMF and methanol, and dried under vacuum at $80{ }^{\circ} \mathrm{C}$ overnight prior to further characterization.

The $\mathrm{Fe}_{2} \mathrm{Mn}$-MIL-88B framework was prepared using a process similar to that used to prepare Fe-MIL-88B, except that $\mathrm{FeCl}_{3} \cdot 6 \mathrm{H}_{2} \mathrm{O}\left(0.47 \mathrm{mmol}\right.$ ) and $\mathrm{Mn}\left(\mathrm{NO}_{3}\right)_{2}$ (solution, $50 \mathrm{wt} \%, 0.53$ $\mathrm{mmol}$ ) were used as the metal salts.

The $\mathrm{Fe}_{2} \mathrm{Co}$-MIL-88B framework was prepared using a process similar to that used to prepare Fe-MIL-88B, except that $\mathrm{FeCl}_{3} \cdot 6 \mathrm{H}_{2} \mathrm{O}(0.57 \mathrm{mmol})$ and $\mathrm{Co}\left(\mathrm{NO}_{3}\right)_{2} \cdot 6 \mathrm{H}_{2} \mathrm{O}(0.43 \mathrm{mmol})$ were used as the metal salts.

The $\mathrm{Fe}_{2} \mathrm{Ni}$-MIL-88B framework was prepared using a process similar to that used to prepare Fe-MIL-88B, except that $\mathrm{FeCl}_{3} \cdot 6 \mathrm{H}_{2} \mathrm{O}(0.57 \mathrm{mmol})$ and $\mathrm{Ni}\left(\mathrm{NO}_{3}\right)_{2} \cdot 6 \mathrm{H}_{2} \mathrm{O}(0.43 \mathrm{mmol})$ were used as the metal salts.

\subsection{Physical characterization}

The morphologies of the frameworks were analyzed using scanning electron microscopy (SEM, field-emission JSM-7800F microscope) and transmission electron microscopy (TEM, JEM-2100 field emission electron microscope); energy-dispersive X-ray spectroscopy (EDX) mapping was recorded using a FEI Tecnai G2 F20. Powder X-ray diffraction (XRD) studies were performed using a RIGAKU Miniflex600 diffractometer with $\mathrm{Cu} K_{\alpha}$ radiation $(\lambda=1.54178 \AA)$. Fourier-transform infrared (FT-IR) spectra were collected with a Thermo Nicolet 6700 Spectrometer using $\mathrm{KBr}$ pellets; the region below $750 \mathrm{~cm}^{-1}$ was recorded in greater detail using a Nicolet iS50 Spectrometer. The elemental compositions of the materials were analyzed using inductively coupled plasma optical emission spectrometry (ICP-OES, ICP-OES 7300DV). $\mathrm{N}_{2}$ adsorption-desorption isotherms were recorded using a Quantachrome Autosorb-iQ instrument at $77 \mathrm{~K}$. Before analysis, all samples were degassed at $150{ }^{\circ} \mathrm{C}$ for $6 \mathrm{~h}$. X-ray photoelectron spectra (XPS) were collected using a Thermo ESCALAB 250Xi spectrometer with $\mathrm{Al} K_{\alpha}$ radiation $(h v=1486.6 \mathrm{eV})$, and the $\mathrm{C} 1 s$ binding energy at $284.5 \mathrm{eV}$ was used to correct all the measured binding energy values.

\subsection{Electrochemical measurements}

All electrochemical measurements were conducted using a three-electrode cell setup and a computer-controlled bipotentiostat (Pine Company). A saturated calomel electrode was used as the reference electrode, and the electrode potential was calibrated and converted to that of the reversible hydrogen electrode (RHE). The counter electrode was a carbon rod electrode. To prepare the working electrodes, samples $(2.5 \mathrm{mg})$ of the MOFs were mixed with Vulcan XC-72 (Cabot) (2.5 mg) and dispersed in $2 \mathrm{~mL}$ ethanol containing $30 \mu \mathrm{L}$ of Nafion solution ( $5 \mathrm{wt} \%$, Dupont). After $3 \mathrm{~h}$ of sonication, $30 \mu \mathrm{L}$ of the resulting homogeneous ink was deposited onto a pre-cleaned glassy carbon rotating disk electrode (GC-RDE, $0.196 \mathrm{~cm}^{-2}$ ). Commercial iridium black (Johnson Matthey) and Vulcan XC-72 were physically mixed to produce an $\mathrm{Ir} / \mathrm{C}$ composite containing 20 $\mathrm{wt} \%$ of iridium. The obtained $\mathrm{Ir} / \mathrm{C}$, which was oxidized to
$\mathrm{IrO}_{x} / \mathrm{C}$ under the anodic working conditions, was used as a benchmark catalyst for comparison. RDE measurements of the samples were performed in $\mathrm{O}_{2}$ or $\mathrm{N}_{2}$-purged $0.1 \mathrm{M} \mathrm{KOH}$ electrolyte at a scan rate of $10 \mathrm{mV} \mathrm{s}^{-1}$ at $1600 \mathrm{rpm}$. Unless otherwise noted, all curves were iR-corrected. Electrochemical impedance spectra (EIS) were collected using a Solartron 1287A potentiostat in combination with a 1260 FRA unit at an amplitude of $10 \mathrm{mV}$ and a frequency scan range of $10 \mathrm{kHz}$ to 100 $\mathrm{mHz}$, and were conducted at either open circuit potential or $1.580 \mathrm{~V}$ vs RHE. The stability investigation was performed in $\mathrm{N}_{2}$-purged $0.1 \mathrm{M} \mathrm{KOH}$ using carbon cloth on which a $1 \mathrm{mg} \mathrm{cm}^{-2}$ loading of the catalyst had been deposited as the working electrode. Chronoamperometry was conducted for $10 \mathrm{~h}$ at a potential of $1.703 \mathrm{~V}$ (vs RHE, without iR-correction), and OER polarization curves before and after the stability test were recorded at a scan rate of $50 \mathrm{mV} \mathrm{s}^{-1}$.

\subsection{DFT calculation}

All calculations were conducted using the $\mathrm{DMol}^{3}$ code embedded in Materials Studio (Accelrys, SanDiego, CA) [39], and considered both spin polarization and long-range dispersion correction via Grimme's scheme [40]. Exchange and correlation effects were described using the generalized gradient approximation with the Perdew-Burke-Ernzerhof (PBE) functional [41]. All electrons core treat method was implemented and the double numerical atomic orbital augmented by a polarization function was chosen as the basis set [42]. During geometrical optimization, the basis set cut-off was set at $5.2 \AA$. The convergence tolerances for the geometry optimization were set to $10^{-5} \mathrm{Ha}$ for energy, $0.002 \mathrm{Ha} / \AA ̊ \AA$ for force, and $0.005 \AA$ for displacement. The electronic SCF tolerance was set to $10^{-6} \mathrm{Ha}$. A Fermi smearing parameter of 0.005 Ha was used in the calculations. The reciprocal space was sampled with Gamma points for the relaxation calculations and electronic structure computations. A vacuum region with a thickness of greater than $15 \AA$ was added to avoid artificial interactions between $\mathrm{Fe}_{2} \mathrm{M}-\mathrm{MIL}-88 \mathrm{~B}$ and its images.

\section{Results and discussion}

$\mathrm{Fe}_{2} \mathrm{M}-\mathrm{MIL}-88 \mathrm{~B}$ ( $\mathrm{M}=\mathrm{Mn}, \mathrm{Fe}, \mathrm{Co}$, or Ni) frameworks were synthesized via the solvothermal reaction of the appropriate metal ions and terephthalic acid; their hexagonal structure was obtained through the connection of the trinuclear oxo-centered metal clusters $\left(\mathrm{Fe}_{2} \mathrm{MO}\right)$ to the 1,4-bezenedicarboxylate (BDC) ligands $[35,43]$. The chemical formula of the frameworks can be expressed as $\left[\mathrm{Fe}_{2} \mathrm{MO}(\mathrm{BDC})_{3}\left(\mathrm{H}_{2} \mathrm{O}\right)_{2}(\mathrm{X})\right]_{n}$, where $\mathrm{X}$ is the anion coordinated to the metal ions of the $\mathrm{Fe}_{2} \mathrm{MO}$ unit [36]. The morphologies of the samples were characterized using SEM and TEM as shown in Fig. 1. All the MOFs showed a well-defined elongated hexagonal bipyramidal morphology, which is typical of MIL-88B structures [44,45]. The size distributions obtained from the SEM images indicated that Fe-MIL-88B was much thinner and longer than the other MOFs, with a length of $763 \pm$ $66.5 \mathrm{~nm}$ and a diameter of $83.6 \pm 13.5 \mathrm{~nm}$, while $\mathrm{Fe}_{2} \mathrm{Mn}-\mathrm{MIL}-88 \mathrm{~B}$ was the shortest and thickest, with a length of 


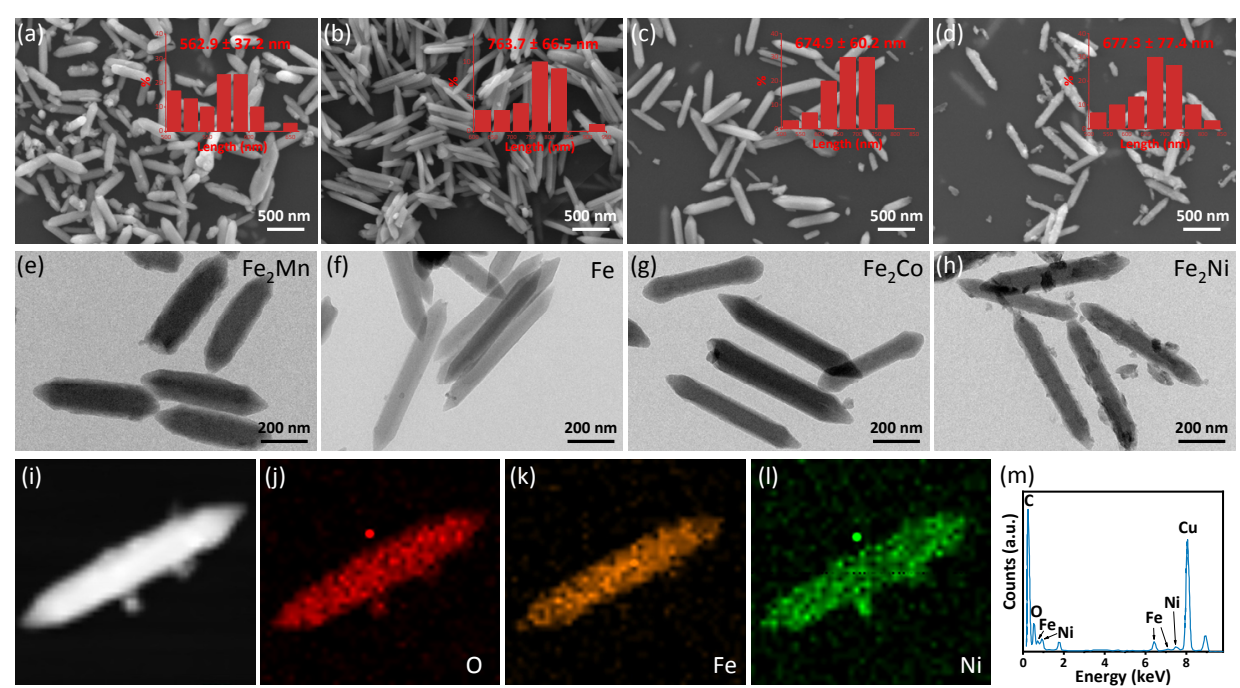

Fig. 1. SEM and TEM images of Fe $\mathrm{F}_{2}$ Mn-MIL-88B (a,e), Fe-MIL-88B (b,f), Fe $\mathrm{C}_{2} \mathrm{Co}-\mathrm{MIL}-88 \mathrm{~B}$ (c,g), and Fe $\mathrm{N}_{2} \mathrm{Ni}-\mathrm{MIL}-88 \mathrm{~B}$ (d,h) (inset: distributions of the length of the samples). TEM images of Fe $2 \mathrm{Ni}-\mathrm{MIL}-88 \mathrm{~B}(\mathrm{i})$ and the corresponding elemental mapping of oxygen (j), iron (k), and nickel (l), along with the corresponding EDX spectra $(\mathrm{m})$ in the selected region.

$562.9 \pm 37.2 \mathrm{~nm}$ and a diameter of $136.8 \pm 13.6 \mathrm{~nm}$. $\mathrm{Fe}_{2} \mathrm{Ni}-\mathrm{MIL}-88 \mathrm{~B}$ and $\mathrm{Fe}_{2} \mathrm{Co}$-MIL-88B were very similar in size, with lengths of $677.3 \pm 77.4$ and $674.9 \pm 60.2 \mathrm{~nm}$ and diameters of $127.3 \pm 19.0$ and $120.7 \pm 15.9 \mathrm{~nm}$, respectively. In addition, in the EDX elemental mapping images of $\mathrm{Fe}_{2} \mathrm{Ni}-\mathrm{MIL}-88 \mathrm{~B}$ (Fig. 1), $\mathrm{Fe}, \mathrm{Ni}$, and $\mathrm{O}$ are all clearly observed, and no obvious elemental segregation was found in the selected region.

The structure of $\mathrm{Fe}_{2} \mathrm{M}-\mathrm{MIL}-88 \mathrm{~B}$ was further characterized using XRD and FT-IR. The XRD patterns shown in Fig. 2(a) demonstrate that the diffraction peaks of the as-prepared $\mathrm{Fe}_{2} \mathrm{M}$-MIL-88B were almost identical to those attributed to MIL-88B structures $[38,46,47]$. The slight differences in the peak positions and intensities of the XRD patterns of the other frameworks were attributed to the different host-guest interactions of the flexible MIL-88B framework when $\mathrm{Fe}^{3+}$ was partially replaced by another metal ion. Analysis of the FT-IR spectra provided information about the functional groups of Fe2M-MIL-88B. For comparison, the FT-IR spectrum of terephthalic acid, which was consistent with published reports [48], is also shown in Fig. 2(b). The adsorption peak of $v_{\text {as }}(-\mathrm{COO}-)$ for pure terephthalic acid appeared at $1684 \mathrm{~cm}^{-1}$, but in the spectrum of $\mathrm{Fe}_{2} \mathrm{M}-\mathrm{MIL}-88 \mathrm{~B}$, no obvious peak was observed at this position. Instead, $v_{\text {as }}(-\mathrm{COO}-)$ and $v_{\mathrm{s}}(-\mathrm{COO}-)$ adsorption bands corresponding to the coordination bonds between the ligands and the trinuclear oxo-centered metal clusters were present at 1583 and $1397 \mathrm{~cm}^{-1}$, indicating the absence of free ligand in the as-prepared materials and the coordination of all the ligands to metal clusters $[48,49]$. Additionally, the peak at $751 \mathrm{~cm}^{-1}$, which is attributed to the vibration of the $\mathrm{C}-\mathrm{H}$ bonds of benzene rings, further demonstrated the presence of coordinated organic ligands [44,49]. Detailed analysis of the vibration of the trinuclear clusters in the frameworks was conducted based on the peaks at wavelengths below $750 \mathrm{~cm}^{-1}$ shown in Fig. 2(c). For Fe-MIL-88B, the vibration of the central oxygen in the planar $\mathrm{Fe}_{3} \mathrm{O}$ cluster with $D_{3 h}$ symmetry produced an adsorption peak at approximately $613 \mathrm{~cm}^{-1}$. However, when one iron in the trinuclear metal cluster was replaced with another metal ion, the symmetry was reduced from $D_{3 h}$ to $C_{2 v}$ [49]. For this reason, the intensity of this band was obviously lower in the mixed-metal cluster samples, while the band corresponding to $\mathrm{Fe}_{2} \mathrm{MO}\left(\mathrm{M}=\mathrm{Mn}, \mathrm{Co}\right.$, or $\mathrm{Ni}$ ) at $695 \mathrm{~cm}^{-1}$ was prominent. Additionally, the peaks from 540 to $550 \mathrm{~cm}^{-1}$ correspond to bonds between the metal ions and the carboxylic groups of the BDC ligands $[44,47,48]$. The positions of these peaks varied de-
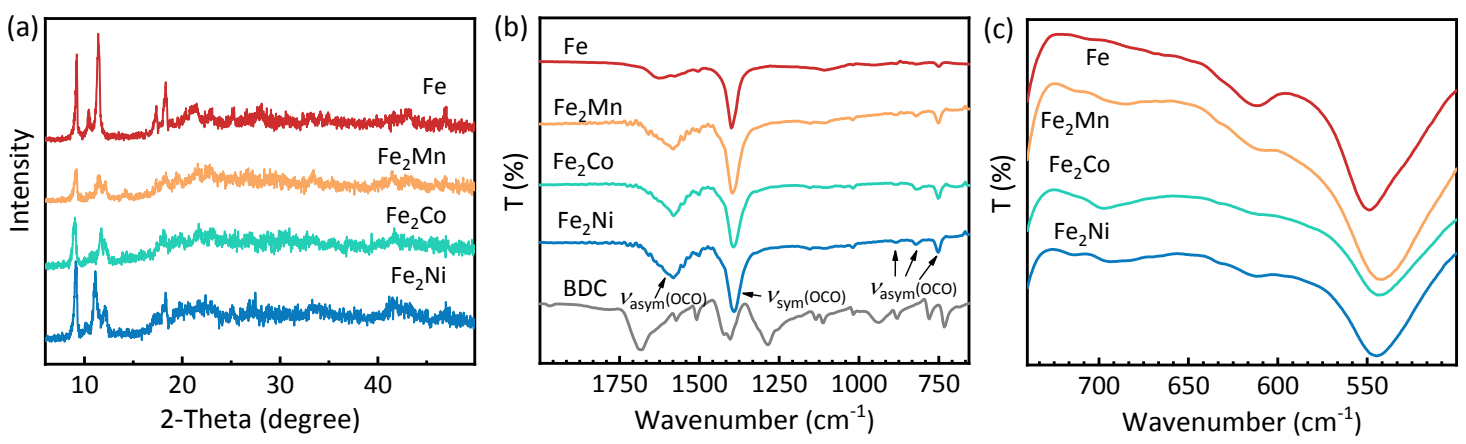

Fig. 2. XRD patterns (a) and FT-IR spectra (b,c) of $\mathrm{Fe}_{2} \mathrm{M}-\mathrm{MIL}-88 \mathrm{~B}$. 

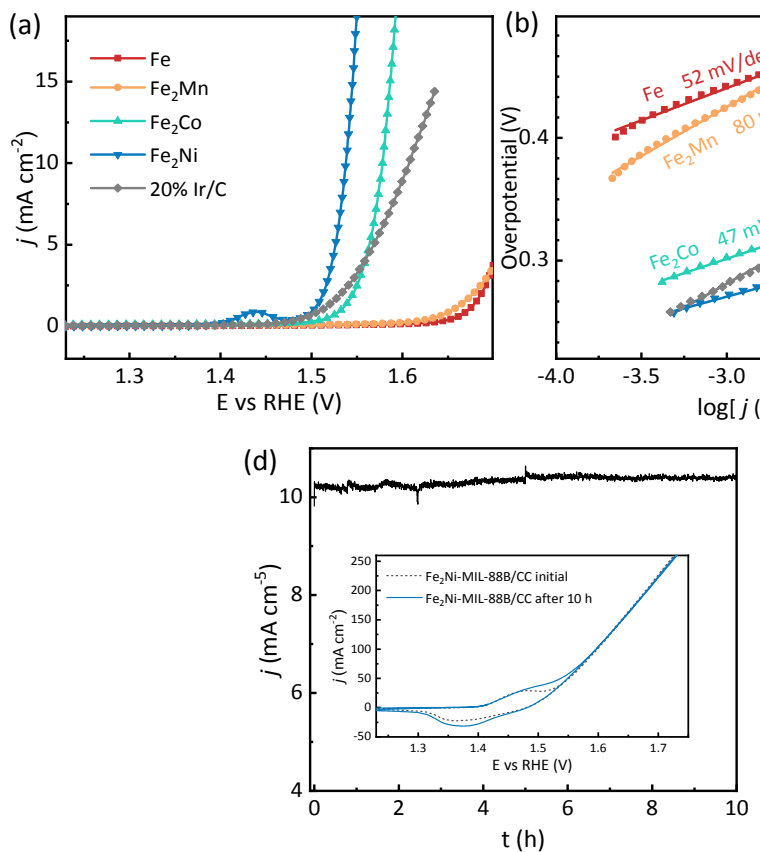
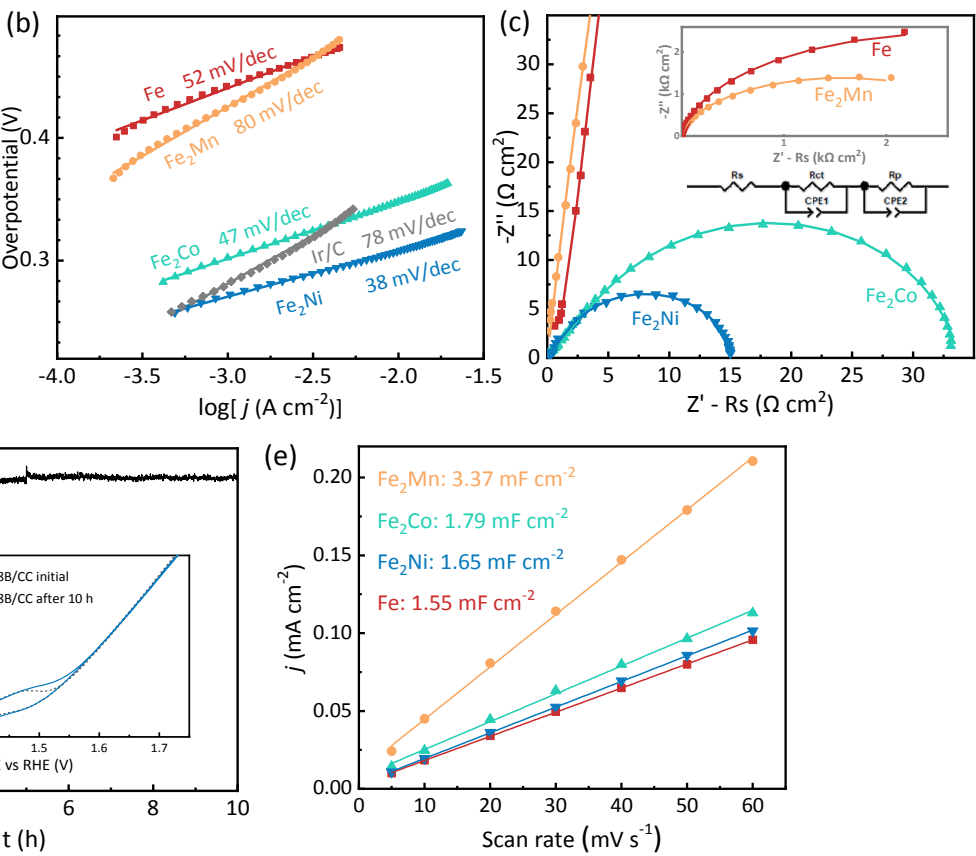

Fig. 3. OER polarization curves (a) and Tafel plots (b) calculated from the polarization curves of Fe 2 M-MIL-88B and $20 \%$ Ir/C in $\mathrm{O}_{2}$-saturated $0.1 \mathrm{M}$ $\mathrm{KOH}$; (c) EIS spectra of $\mathrm{Fe}_{2} \mathrm{M}-\mathrm{MIL}-88 \mathrm{~B}$ at an overpotential of $350 \mathrm{mV}$ with an inset showing the equivalent circuit model (symbols: raw data; lines: linear fit results); (d) Chronoamperometry results of $\mathrm{Fe}_{2} \mathrm{Ni}-\mathrm{MIL}-88 \mathrm{~B} / \mathrm{CC}$ and OER polarization curves before (dashed curve) and after (solid curve) the stability test (without iR-correction); (e) ECSA of Fe 2 M-MIL-88B calculated from LSV measurements performed in a non-faradaic region at different scan rates.

pending on the metal ions in the framework, indicating successful coordination between the linkers and the different metal ions. All the above results clearly prove the formation of the MIL-88B structure in all the materials and confirm the successful synthesis of $\mathrm{Fe}_{2} \mathrm{MO}$ clusters in $\mathrm{Fe} 2 \mathrm{M}-\mathrm{MIL}-88 \mathrm{~B}$.

The electrocatalytic performance of the synthesized $\mathrm{Fe}_{2} \mathrm{M}-\mathrm{MIL}-88 \mathrm{~B}$ catalysts toward the OER was directly measured in $\mathrm{O}_{2}$-purged $0.1 \mathrm{M} \mathrm{KOH}$ using a standard three-electrode system; Vulcan XC-72 carbon powder was mixed with the MOFs to increase their conductivity. Since iron was the main constituent of all the catalysts, the possible influence of iron impurities in the electrolyte could be ignored; thus, the $\mathrm{KOH}$ electrolyte was used without further purification. For comparison, $20 \mathrm{wt} \%$ $\mathrm{Ir} / \mathrm{C}$, which is oxidized to $\mathrm{IrO}_{\mathrm{x}} / \mathrm{C}$ at high anodic potential, was utilized as a benchmark catalyst. The electrocatalytic performance of $\mathrm{Fe}_{2} \mathrm{M}-\mathrm{MIL}-88 \mathrm{~B}$ was investigated using linear sweep voltammetry (LSV), and the results are shown in Fig. 3(a). A typical anodic peak from 1.400 to $1.470 \mathrm{~V}$ vs RHE, which could correspond to the oxidation of $\mathrm{Ni}^{2+}[50,51]$, appeared in the LSV curve of $\mathrm{Fe}_{2} \mathrm{Ni}-\mathrm{MIL}-88 \mathrm{~B}$, while no significant anodic peaks were observed for the other catalysts in the examined potential range. Compared to the OER onset overpotential of Fe-MIL-88B (396 mV), the values of $\mathrm{Fe}_{2} \mathrm{Mn}-\mathrm{MIL}-88 \mathrm{~B}, \mathrm{Fe}_{2} \mathrm{Co}-\mathrm{MIL}-88 \mathrm{~B}$, and $\mathrm{Fe}_{2} \mathrm{Ni}-\mathrm{MIL}-88 \mathrm{~B}$ were reduced $(363,273$, and $248 \mathrm{mV}$, respectively). The incorporation of the second metal obviously enhanced the electrocatalytic activity to different degrees. At low current density ( $<5 \mathrm{~mA} \mathrm{~cm}^{-2}$ ), $\mathrm{Fe}_{2} \mathrm{Mn}$-MIL-88B could drive the OER with a lower overpotential than that of Fe-MIL-88B. However, both these catalysts exhibited poor OER electrocatalytic activities and required overpotentials of greater than $470 \mathrm{mV}$ at $10 \mathrm{~mA} \mathrm{~cm}-2$, which is the approximate current density of the anode in a solar water-splitting device with an efficiency of $10 \%$ under 1 sun illumination [52]. When nickel or cobalt was introduced in the samples, their OER electrocatalytic performance was significantly enhanced. $\mathrm{Fe}_{2} \mathrm{Co}-\mathrm{MIL}-88 \mathrm{~B}$ and $\mathrm{Fe}_{2}$ Ni-MIL-88B exhibited overpotentials of 348 and $307 \mathrm{mV}$, respectively, which were superior to that of the benchmark Ir/C electrocatalyst (376 mV). Fe2Ni-MIL-88B clearly outperformed the other tested samples, and its catalytic activity was comparable to that of other reported MOF OER electrocatalysts (Table 1).

To further investigate the OER catalytic properties of these samples, the Tafel slopes were calculated from the polarization plots. As shown in Fig. 3(b), Fe 2 Ni-MIL-88B exhibited a Tafel slope of $38 \mathrm{mV} \mathrm{dec}^{-1}$, which was much smaller than those of the

\section{Table 1}

Comparison of the electrocatalytic OER performance of $\mathrm{Fe}_{2} \mathrm{M}$-MIL-88B with that of other reported MOF electrocatalysts tested in $0.1 \mathrm{M} \mathrm{KOH}$ on a GC-RDE.

\begin{tabular}{lcccc}
\hline Catalyst & $\begin{array}{c}\text { Loading } \\
\left(\mathrm{mg} \mathrm{cm}^{-2}\right)\end{array}$ & $\begin{array}{c}\eta(\mathrm{mV}) \\
@ 10 \mathrm{~mA} \mathrm{~cm}^{-2}\end{array}$ & $\begin{array}{c}\text { Tafel slope } \\
\left(\mathrm{mV} \mathrm{dec}^{-1}\right)\end{array}$ & Ref. \\
\hline $\mathrm{Fe}_{2}$ Ni-MIL-88B & 0.191 & 307 & 38 & This work \\
$\mathrm{Fe}_{2} \mathrm{Co}-\mathrm{MIL}-88 \mathrm{~B}$ & 0.191 & 348 & 47 & This work \\
MAF-X27-OH & 0.18 & 461 & 66 & {$[28]$} \\
$\mathrm{NiFe}-M O F$ & 0.3 & 406 & - & {$[27]$} \\
$\mathrm{Ti}_{3} \mathrm{C}_{2} \mathrm{~T}_{x}$-CoBDC & 0.208 & 410 & 48.2 & {$[30]$} \\
$\mathrm{Fe}_{3}$-Co & 0.2 & 283 & 43 & {$[29]$} \\
$\mathrm{Fe}_{2}$ 2D-Co-NS & 0.2 & 282 & 59 & {$[31]$} \\
$\mathrm{FeCo}-M N S-1.0^{2}$ & 0.36 & 298 & 21.6 & {$[65]$} \\
CTGU-10c2 & 0.14 & 240 & 58 & {$[32]$} \\
\hline
\end{tabular}



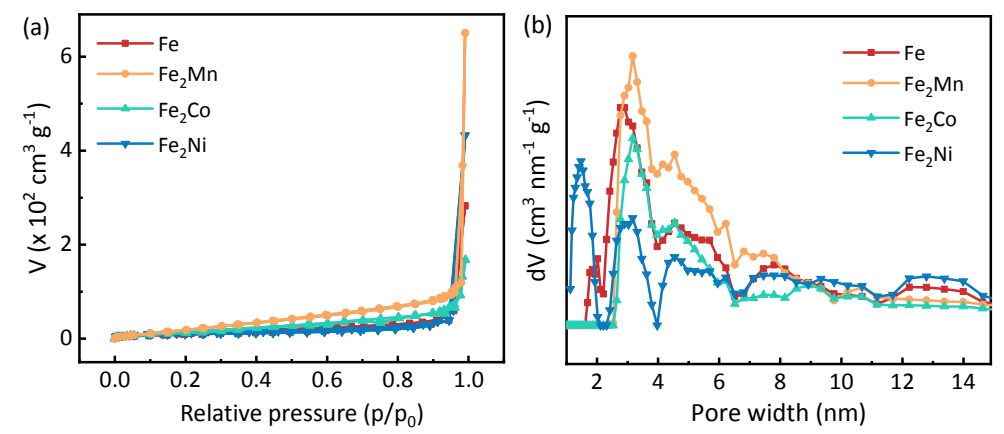

Fig. 4. $\mathrm{N}_{2}$ adsorption-desorption isotherms (a) and pore size distributions (b) of $\mathrm{Fe}_{2} \mathrm{M}-\mathrm{MIL}-88 \mathrm{~B}$.

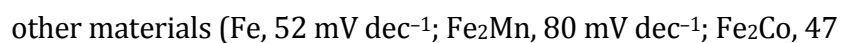

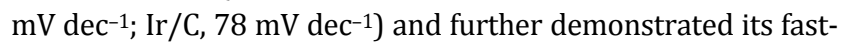
er OER catalytic kinetics. To study the OER kinetics, EIS analyses of the catalysts were performed at an electrode potential of $1.580 \mathrm{~V}$ vs RHE; the results are displayed in Fig. 3(c). The trend in the charge transfer resistance $R_{\mathrm{ct}}\left(\mathrm{Fe}_{2} \mathrm{Ni}, 2.096 \Omega \mathrm{cm}^{2}\right.$; $\mathrm{Fe}_{2} \mathrm{Co}, 6.478 \Omega \mathrm{cm}^{2} ; \mathrm{Fe}_{2} \mathrm{Mn}, 3003 \Omega \mathrm{cm}^{2}$; Fe, $5325 \Omega \mathrm{cm}^{2}$ ) was clearly consistent with the trend in the catalytic activity shown in Fig. 3(a). $\mathrm{Fe}_{2}$ Ni-MIL-88B exhibited the lowest charge transfer resistance, clearly indicating its more efficient charge transfer in the OER.

The short-term electrochemical stability of $\mathrm{Fe}_{2} \mathrm{Ni}$-MIL-88B was also examined using chronoamperometry and is presented in Fig. 3(d). Only a slight change in the OER activity was observed, thus substantiating the durability of $\mathrm{Fe}_{2} \mathrm{Ni}$-MIL-88B in alkaline solutions.

To reveal the underlying reasons for the improved performance of the bimetallic $\mathrm{Fe}_{2} \mathrm{M}$-MIL-88B catalysts, we carefully investigated several possible factors that might affect their electrochemical performance. First, ICP-OES was conducted to investigate the relative proportions of metal in each catalyst. The Fe:M molar ratios ( $\mathrm{M}=\mathrm{Mn}, \mathrm{Co}, \mathrm{Ni})$ were 2.00, 2.29, and 2.02 for $\mathrm{Fe}_{2} \mathrm{Mn}-\mathrm{MIL}-88 \mathrm{~B}, \mathrm{Fe}_{2} \mathrm{Co}-\mathrm{MIL}-88 \mathrm{~B}$, and Fe $2 \mathrm{Ni}-\mathrm{MIL}-88 \mathrm{~B}$, respectively, indicating similar metal contents. We then evalu- ated the electrochemical active surface area (ECSA) of the $\mathrm{Fe}_{2} \mathrm{M}-\mathrm{MIL}-88 \mathrm{~B}$ catalysts by calculating their double-layer capacitance $\left(C_{\mathrm{dl}}\right)$ values from polarization curves measured in the non-Faradaic region. The slopes of the curves in Fig. 3(e), which represent the $C_{\mathrm{dl}}$ values, reveal that $\mathrm{Fe}_{2} \mathrm{Ni}-\mathrm{MIL}-88 \mathrm{~B}\left(C_{\mathrm{dll}}: 1.65\right.$ $\left.\mathrm{mF} \mathrm{cm}{ }^{-2}\right)$ and $\mathrm{Fe}_{2} \mathrm{Co}-\mathrm{MIL}-88 \mathrm{~B}\left(C_{\mathrm{dl}}: 1.79 \mathrm{mF} \mathrm{cm}^{-2}\right)$ had slightly larger ECSAs than monometallic Fe-MIL-88B ( $C_{\mathrm{dl}}: 1.55 \mathrm{mF}$ $\mathrm{cm}^{-2}$ ). These results indicated that the incorporation of the second metal slightly increased the surface area of the MOFs, which would afford more active sites and promote the OER process. However, the $C_{\mathrm{dl}}$ value doubled to $3.37 \mathrm{mF} \mathrm{cm}^{-2}$ for $\mathrm{Fe}_{2} \mathrm{Mn}-\mathrm{MIL}-88 \mathrm{~B}$, which was in agreement with the specific surface area results of the $\mathrm{N}_{2}$ adsorption-desorption isotherms (Fe-MIL-88B: $35.2 \mathrm{~m}^{2} \mathrm{~g}^{-1}$; Fe2Mn-MIL-88B: $116.4 \mathrm{~m}^{2} \mathrm{~g}^{-1}$; Fe ${ }_{2}$ Co-MIL-88B: $47.9 \mathrm{~m}^{2} \mathrm{~g}^{-1}$; Fe 2 Ni-MIL-88B: $35.7 \mathrm{~m}^{2} \mathrm{~g}^{-1}$ ) in Fig. 4. Based on the poor OER catalytic activity of $\mathrm{Fe}_{2} \mathrm{Mn}-\mathrm{MIL}-88 \mathrm{~B}$, it was concluded that the ECSA was not the principal factor responsible for the performance enhancement.

To further explore the OER reaction mechanism for Fe-MIL-88B, we measured the OER current density of $\mathrm{Fe}_{2} \mathrm{M}-\mathrm{MIL}-88 \mathrm{~B}$ in alkaline electrolytes with different $\mathrm{pH}$ values (from 12.57 to 13.98) using LSV; the results are shown in Fig. 5(a). The OER reaction order of $\mathrm{pH}$ illustrates how the proton activity affects the OER kinetics of the rate-determining step
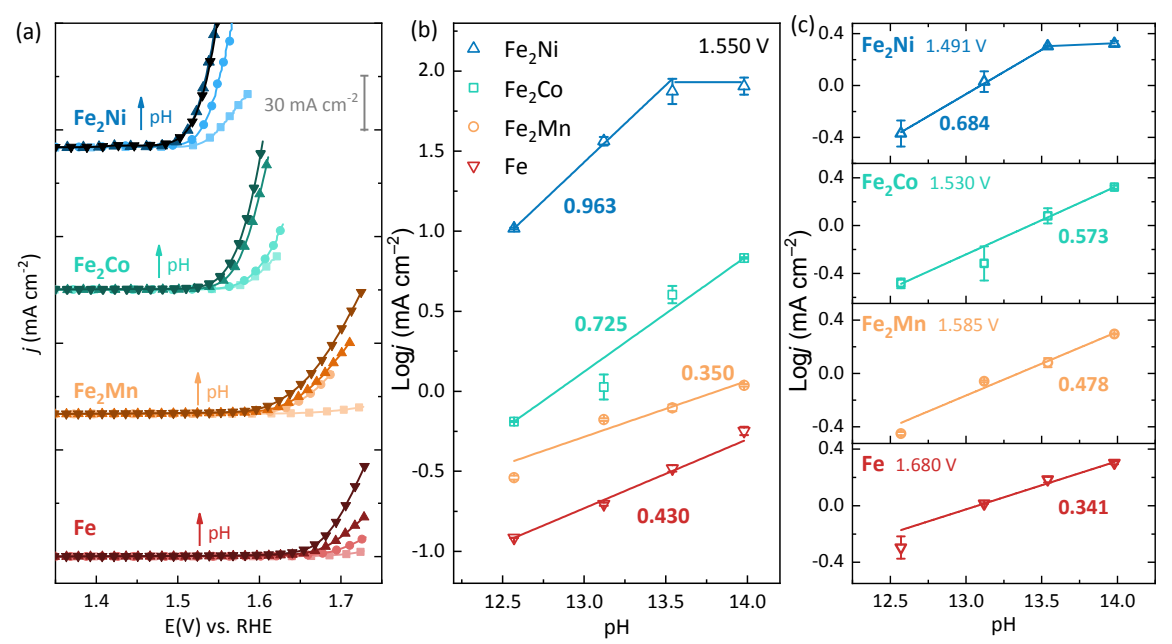

Fig. 5. (a) LSV measurements of the catalysts in $\mathrm{O}_{2}$-purged $\left.\left.0.0316 \mathrm{M} \mathrm{KOH} \mathrm{(pH} \mathrm{12.57,} \mathbf{\bullet}\right), 0.1 \mathrm{M} \mathrm{KOH} \mathrm{(pH} \mathrm{13.12,} \mathrm{\bullet ),} 0.316 \mathrm{M} \mathrm{KOH} \mathrm{(pH} 13.54, \mathbf{\Delta}\right)$, and 1 M KOH (pH 13.98, $\mathbf{\nabla})$. OER current density at (b) $1.550 \mathrm{~V}$ vs. RHE and the indicated potential (c) after iR-correction at the investigated pH values. 
(RDS). Thus, important information about the reaction process can be obtained from the reaction order $\rho=(\partial \log (\mathrm{i}) / \partial \mathrm{pH})_{E}$ [53]. The reaction order $\rho$ is zero for the traditional proton-electron coupled mechanistic routes when RHE is used as the reference electrode; as a result, the OER activity should be $\mathrm{pH}$-independent under these conditions. However, on the RHE scale, all four catalysts exhibited pH-dependent OER activity at a potential of $1.550 \mathrm{~V}$, which is a commonly used potential value in the literature [54,55] (For Fe 2 Ni-MIL-88B, the measured activities at $\mathrm{pH}$ values of 13.54 and 13.98 were very similar. A similar phenomenon has been reported by other researchers. This phenomenon might be related to the accelerating effect of higher-pH electrolytes on the oxidation of nickel centers [56]. However, in the $\mathrm{pH}$ range we focused upon, namely, the region near 13.12 in $0.1 \mathrm{M} \mathrm{KOH}$, the slope of the linear fitting is obviously non-zero. Thus, pH-dependence of the OER activity of $\mathrm{Fe}_{2} \mathrm{Ni}-\mathrm{MIL}-88 \mathrm{~B}$ is conceivable). For Fe-MIL88B and $\mathrm{Fe}_{2} \mathrm{Mn}-\mathrm{MIL88B}$, which showed poor electrocatalytic perfor- mance, the potential of $1.550 \mathrm{~V}$ may have been too low for detectable OER current to be produced. Thus, measurements were also conducted at the potential required to achieve a current density of $2 \mathrm{~mA} \mathrm{~cm}^{-2}$ in $1 \mathrm{M} \mathrm{KOH}$; these results are shown in Fig. 5(c). All four catalysts exhibited pH-dependent OER activity. This dependence indicated the existence of decoupled proton and electron transfer steps in the catalytic process [57], in which the RDS may be a proton transfer step or an acid/base equilibrium prior to the proton transfer step [53]. Therefore, the acid dissociation constant $K_{\mathrm{a}}$ is important for the transfer of protons, which is the equilibrium constant of a surface active site under deprotonation $[53,55,58]$. Thus, investigation of the electronic structure of the $\mathrm{Fe}_{2} \mathrm{M}$-MIL-88B materials was necessary.

The chemical composition and electronic properties of the as-obtained $\mathrm{Fe}_{2} \mathrm{M}-\mathrm{MIL}-88 \mathrm{~B}$ materials were examined by XPS analysis; the results are shown in Fig. 6. The full survey patterns in Fig. 6(a) demonstrate the existence of $\mathrm{Fe}, \mathrm{O}, \mathrm{C}$, and the
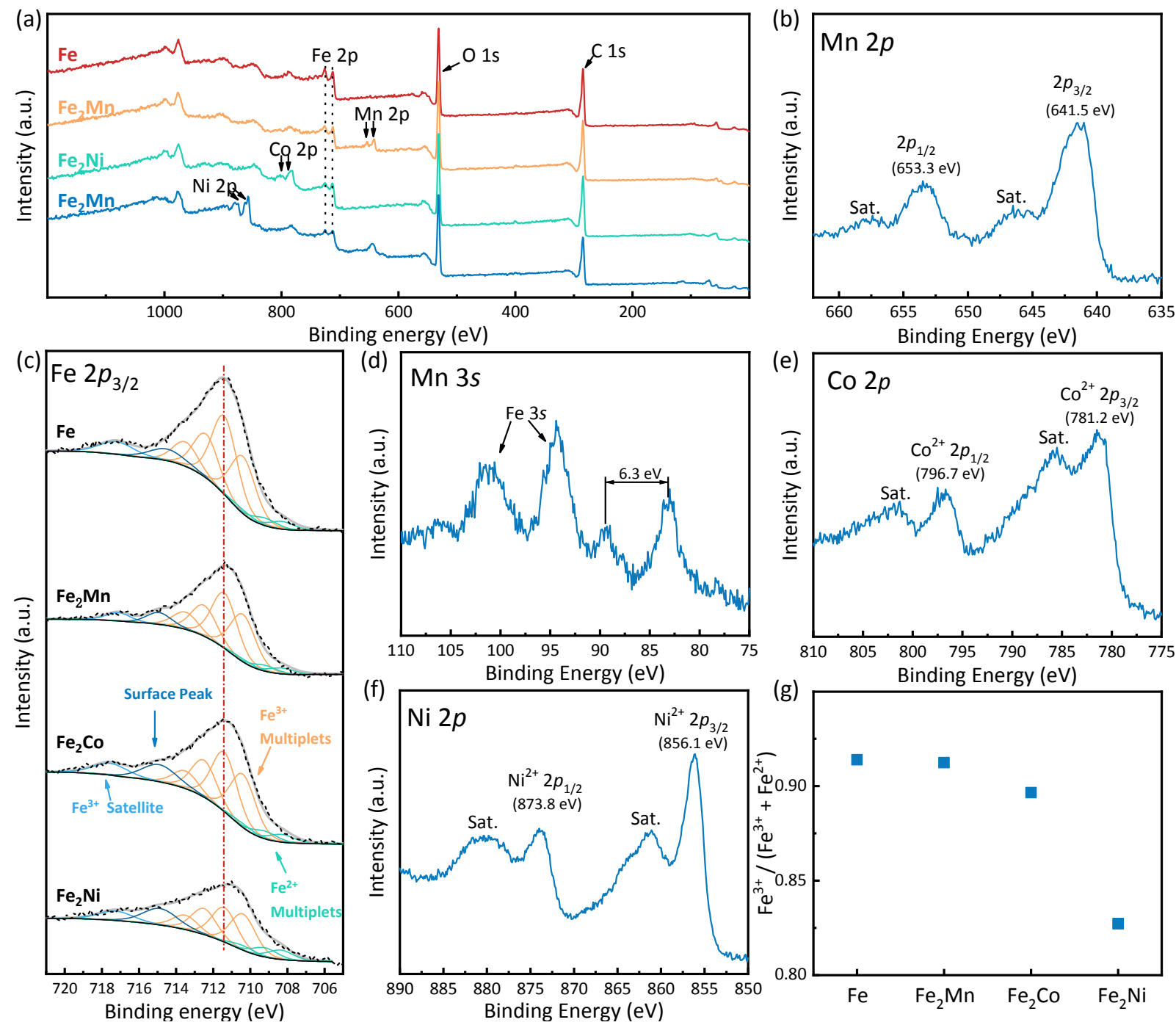

Fig. 6. (a) XPS survey patterns of all the samples; (b) Mn $2 p$ high-resolution spectrum of Fe ${ }_{2}$ Mn-MIL-88B; (c) Fe $2 p$ high-resolution spectra of all samples (Dashes: raw data. Gray line: fitting results); (d) Mn $3 s$ high-resolution XPS spectrum of Fe 2 Mn-MIL-88B; (e) Co $2 p$ and (f) Ni $2 p$ high-resolution spectra of $\mathrm{Fe}_{2} \mathrm{Co}-\mathrm{MIL}-88 \mathrm{~B}$ and $\mathrm{Fe}_{2} \mathrm{Ni}-\mathrm{MIL}-88 \mathrm{~B}$, respectively; (g) $\mathrm{Fe}^{3+}$ content calculated from the fitting results of Fe $2 \mathrm{M}-\mathrm{MIL}-88 \mathrm{~B}$. 
expected metal elements in the bimetallic MOFs. Detailed information regarding the oxidation states of the metal elements was obtained from the high-resolution XPS spectra. As shown in Fig. 6(b), the Mn $2 p$ spectrum of $\mathrm{Fe}_{2} \mathrm{Mn}-\mathrm{MIL}-88 \mathrm{~B}$ contained spin-orbit-split $2 p_{1 / 2}$ and $2 p_{3 / 2}$ peaks with binding energies of 641.5 and $653.3 \mathrm{eV}$, respectively. Two satellite peaks were observed at approximately $\sim 4.8 \mathrm{eV}$ higher binding energy than the $2 p$ peaks; such satellites are a feature of the $\mathrm{Mn}^{2+}$ state [59]. To identify the Mn oxidation state in a straightforward manner, the Mn $3 s$ peaks resulting from the coupling of the non-ionized $3 s$ electrons with $3 d$ valence electrons were also investigated, as the magnitude of the splitting of these peaks is diagnostic of the oxidation state [59-61]. The measured energy separation of $\sim 6.3 \mathrm{eV}$ in Fig. 6(d) further confirmed that the Mn oxidation state was 2. For Fe 2 Co-MIL-88B, the Co $2 p$ XPS spectrum in Fig. 6(e) exhibited two characteristic peaks at 796.7 and $781.2 \mathrm{eV}$, along with strong satellite peaks at 802.0 and $785.6 \mathrm{eV}$, indicating that the main oxidation state of cobalt was $2[26,29]$. From the two characteristic peaks at 873.8 and $856.1 \mathrm{eV}$ in the $\mathrm{Ni} 2 p$ spectrum of $\mathrm{Fe}_{2} \mathrm{Ni}-\mathrm{MIL}-88 \mathrm{~B}$ in Fig. 6(f), it was concluded that the predominant oxidation state of the $\mathrm{Ni}$ ions was $\mathrm{Ni}^{2+}$ $[62,63]$.

The iron oxidation states were analyzed in great detail. As shown in Fig. 6(c), all four Fe $2 p_{3 / 2}$ spectra were fitted using Gupta and Sen (GS) multiplets, high-binding-energy surface structures, and satellite peaks [64]. Based on the GS multiplet model, the series of peaks at 710.4, 711.4, 712.4, and $713.5 \mathrm{eV}$ were assigned to the $\mathrm{Fe}^{3+}$ oxidation state, and the peaks at 708.3, 709.2, and 710.4 eV were attributed to $\mathrm{Fe}^{2+}$. The main oxidation state of iron was clearly 3 . However, when a second metal was incorporated to the MOFs, the peaks shifted to lower binding energy and the $\mathrm{Fe}^{3+} / \mathrm{Fe}^{2+}$ intensity ratio decreased, indicating the altered electronic properties of the iron ions as well as the interactions between iron and the second metal. The most distinct change was observed for $\mathrm{Fe}_{2} \mathrm{Ni}-\mathrm{MIL}-88 \mathrm{~B}$. As shown in Fig. 6(g), Fe 2 Ni-MIL-88B had an $\mathrm{Fe}^{3+} /\left(\mathrm{Fe}^{3+}+\mathrm{Fe}^{2+}\right)$ peak area ratio of $82.72 \%$, which was lower than those of Fe-MIL-88B (91.39\%), $\mathrm{Fe}_{2} \mathrm{Mn}-\mathrm{MIL}-88 \mathrm{~B} \quad$ (91.24\%), and $\mathrm{Fe}_{2} \mathrm{Co}-\mathrm{MIL}-88 \mathrm{~B}(89.65 \%)$. This suggests a relatively strong coupling effect between iron and nickel, which may explain the major improvement in the OER electrochemical activity of $\mathrm{Fe}_{2} \mathrm{Ni}$-MIL-88B compared with that of monometallic Fe-MIL-88B.

The charge transfer phenomenon can be well explained by the electronic structure of the MOFs (Fig. 7). The valence electron configuration of $\mathrm{Fe}^{3+}$ is $3 d^{5}$ with a high-spin state, which

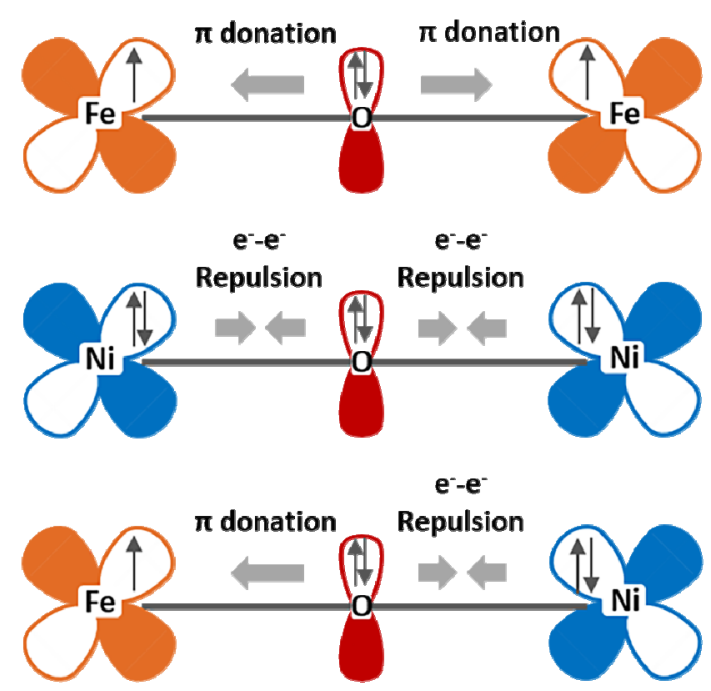

Fig. 7. Schematic representation of the electronic coupling between $\mathrm{Fe}$ and $\mathrm{Ni}$ in $\mathrm{Fe}_{2} \mathrm{Ni}-\mathrm{MIL}-88 \mathrm{~B}$.

means that $\mathrm{Fe}^{3+}$ has unpaired electrons in the $\pi$-symmetry $\left(t_{2 \mathrm{~g}}\right)$ $d$-orbitals that interact with the bridging $\mathrm{O}^{2-}$ via $\pi$-donation [26]. $\mathrm{Mn}^{2+}$ has a similar valence electronic configuration of $3 d^{5}$ and a high-spin state; thus, its influence on the electronic structure of $\mathrm{Fe}^{3+}$ was expected to be slight, which agreed with the electrochemical experiment results. In contrast, the electronic structure of $\mathrm{Ni}^{2+}$ is $3 d^{8}$, with fully occupied $\pi$-symmetry $\left(t_{2 \mathrm{~g}}\right) d$-orbitals. For this reason, the main interaction between the bridging $\mathrm{O}^{2-}$ and $\mathrm{Ni}^{2+}$ is $\mathrm{e}^{-}-\mathrm{e}^{-}$repulsion. When $\mathrm{Ni}$ is doped into the Fe-based MOF, the $\pi$-donation via $\mathrm{Fe}^{3+}$ and the bridging $\mathrm{O}^{2-}$ could be enhanced by the $\mathrm{e}^{-}-\mathrm{e}^{-}$repulsion between the bridging $\mathrm{O}^{2-}$ and $\mathrm{Ni}^{2+}$. Electron would be partially transferred from $\mathrm{Ni}^{2+}$ to $\mathrm{Fe}^{3+}$ via the bridging $\mathrm{O}^{2-}$, creating a strong coupling effect between $\mathrm{Fe}^{3+}$ and $\mathrm{Ni}^{2+}$. A similar coupling phenomenon would be expected between $\mathrm{Fe}^{3+}$ and $\mathrm{Co}^{2+}$ due to the $3 d^{7}$ electronic structure of $\mathrm{Co}^{2+}$ with low spin [65], as suggested by the results of the DFT calculations of the spin states of the metals (Table 2). The XPS results also demonstrated a positive shift in the Fe $2 p$ peak after doping with nickel and cobalt. The larger shift observed for nickel indicates that the coupling effect between $\mathrm{Fe}^{3+}$ and $\mathrm{Ni}^{2+}$ was much stronger than that of $\mathrm{Fe}^{3+}$ with the other metal atoms, which explains the superior OER activity of $\mathrm{Fe}_{2} \mathrm{Ni}-\mathrm{MIL}-88 \mathrm{~B}$. These results clearly illustrate the coupling effect between iron and different metal atoms in the well-defined MOF structure. The strong synergy between the metal sites modifies the electronic structure, endowing the

Table 2

Energies of $\mathrm{Fe}_{2} \mathrm{M}-\mathrm{MIL}-88 \mathrm{~B}$ with varied Mulliken spin states.

\begin{tabular}{|c|c|c|c|c|}
\hline Initial spin multiplicity & & 1 & 2 & 3 \\
\hline \multirow{2}{*}{$\mathrm{Fe}_{2} \mathrm{Mn}$} & Final spin & $3.82 \times 2,-3.45^{\mathrm{Mn}}$ & $-3.77,1.52,3.68^{\mathrm{Mn}}$ & $-3.80,3.01,3.28^{M n}$ \\
\hline & Energy (Ha) & -4887.845132 & -4887.833044 & -4887.818988 \\
\hline \multirow{2}{*}{$\mathrm{Fe}$} & Final spin & $3.83 \times 2 ; 3.81$ & $3.78,-3.82,1.10$ & $3.75,-3.80,2.08$ \\
\hline & Energy (Ha) & -5000.539747 & -5000.531345 & -5000.533114 \\
\hline \multirow{2}{*}{$\mathrm{Fe}_{2} \mathrm{Co}$} & Final spin & $1.72,-1.40,0.69$ Co & $1.72,-1.37,0.70^{\text {Co }}$ & $1.87,-0.70,0.82^{\mathrm{Co}}$ \\
\hline & Energy (Ha) & -5119.585567 & -5119.585562 & -5119.582236 \\
\hline \multirow{2}{*}{$\mathrm{Fe}_{2} \mathrm{Ni}$} & Final spin & $1.90,-1.86,1.35^{\mathrm{Ni}}$ & $1.66,-2.13,1.23^{\mathrm{Ni}}$ & $1.97,-1.67,1.39^{\mathrm{Ni}}$ \\
\hline & Energy (Ha) & -5245.130615 & -5245.129398 & -5245.130189 \\
\hline
\end{tabular}


catalysts with enhanced OER electrocatalytic performance.

\section{Conclusions}

In summary, a series of iron-based bimetallic MOFs with MIL-88B structure were developed and employed as OER electrocatalysts in alkaline electrolyte due to the tunable structure characteristics of this framework. The well-defined structure of MOFs on the molecular scale makes them useful in the systematic investigation of structure-activity relationships. Notably, the OER activity of the framework was enhanced after doping with a second metal, with the activity following the order $\mathrm{Fe}_{2} \mathrm{Ni}-\mathrm{MIL}-88 \mathrm{~B}>\mathrm{Fe}_{2} \mathrm{Co}$-MIL-88B $>\mathrm{Fe}_{2} \mathrm{Mn}$-MIL-88B. Among them, $\mathrm{Fe}_{2} \mathrm{Ni}$-MIL-88B exhibited the best catalytic performance, requiring only $307 \mathrm{mV}$ of overpotential to achieve an OER current density of $10 \mathrm{~mA} \mathrm{~cm}^{-2}$ and exhibiting a small Tafel slope of

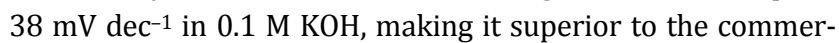
cial Ir/C electrocatalyst. XPS analysis and DFT calculations revealed that partial electron was transferred from $\mathrm{Ni}^{2+}$ to $\mathrm{Fe}^{3+}$ via the bridging $\mathrm{O}^{2-}$, resulting in strong coupling between them and modifying their electronic structure, which in turn improved the OER performance.

\section{Acknowledgement}

The DFT calculations utilized resources at the High Performance Computing Center, Jilin University.

\section{References}

[1] W. Xu, H. Wang, Chin. J. Catal., 2017, 38, 991-1005.

[2] R. D. L. Smith, M. S. Prévot, R. D. Fagan, Z. Zhang, P. A. Sedach, M. K. J. Siu, S. Trudel, C. P. Berlinguette, Science, 2013, 340, 60-63.

[3] L. Kuai, J. Geng, C. Chen, E. Kan, Y. Liu, Q. Wang, B. Geng, Angew. Chem., Int. Ed., 2014, 53, 7547-7551.

[4] M. S. Burke, L. J. Enman, A. S. Batchellor, S. Zou, S. W. Boettcher, Chem. Mater., 2015, 27, 7549-7558.

[5] R. Subbaraman, D. Tripkovic, K.-C. Chang, D. Strmcnik, A. P. Pauli- kas, P. Hirunsit, M. Chan, J. Greeley, V. Stamenkovic, N. M. Markovic, Nat. Mater., 2012, 11, 550-557.

[6] M. Gong, Y. Li, H. Wang, Y. Liang, J. Z. Wu, J. Zhou, J. Wang, T. Regier, F. Wei, H. Dai, J. Am. Chem. Soc., 2013, 135, 8452-8455.

[7] S. Y. Lim, S. Park, S. W. Im, H. Ha, H. Seo, K. T. Nam, ACS Catal., 2019, 235-244.

[8] S. Anantharaj, S. R. Ede, K. Sakthikumar, K. Karthick, S. Mishra, S. Kundu, ACS Catal., 2016, 6, 8069-8097.

[9] W. Chen, Y. Liu, Y. Li, J. Sun, Y. Qiu, C. Liu, G. Zhou, Y. Cui, Nano Lett., 2016, 16, 7588-7596.

[10] X. Xu, F. Song, X. Hu, Nat. Commun., 2016, 7, 12324.

[11] P. Cai, J. Huang, J. Chen, Z. Wen, Angew. Chem., Int. Ed., 2017, 56, $4858-4861$.

[12] J. Li, Q. Zhuang, P. Xu, D. Zhang, L. Wei, D. Yuan, Chin. J. Catal., 2018, 39, 1403-1410.

[13] X. An, D. Shin, J. D. Ocon, J. K. Lee, Y.-I. Son, J. Lee, Chin. J. Catal,, 2014, 35, 891-895.

[14] Y. Guo, Y.-N. Chen, H. Cui, Z. Zhou, Chin. J. Catal., 2019, 40, 1298-1310.

[15] L. Huang, Y. Zou, D. Chen, S. Wang, Chin. J. Catal., 2019, 40, 1822-1840.

[16] S. Trasatti, Electrochim. Acta, 1984, 29, 1503-1512.

[17] S. Trasatti, J. Electroanal. Chem., 1980, 111, 125-131.

[18] M. E. G. Lyons, M. P. Brandon, J. Electroanal. Chem., 2010, 641, 119-130.

[19] F. Calle-Vallejo, O. A. Díaz-Morales, M. J. Kolb, M. T. M. Koper, ACS Catal., 2015, 5, 869-873.

[20] D. A. Corrigan, J. Electrochem. Soc., 1987, 134, 377-384.

[21] S. Zou, M. S. Burke, M. G. Kast, J. Fan, N. Danilovic, S. W. Boettcher, Chem. Mater., 2015, 27, 8011-8020.

[22] M. S. Burke, S. Zou, L. J. Enman, J. E. Kellon, C. A. Gabor, E. Pledger, S. W. Boettcher, J. Phys. Chem. Lett., 2015, 6, 3737-3742.

[23] J. Shi, Chem. Rev., 2013, 113, 2139-2181.

[24] M. W. Louie, A. T. Bell, J. Am. Chem. Soc., 2013, 135, 12329-12337.

[25] D. Friebel, M. W. Louie, M. Bajdich, K. E. Sanwald, Y. Cai, A. M. Wise, M.-J. Cheng, D. Sokaras, T.-C. Weng, R. Alonso-Mori, R. C. Davis, J. R. Bargar, J. K. Nørskov, A. Nilsson, A. T. Bell, J. Am. Chem. Soc., 2015, 137, 1305-1313.

[26] S. Zhao, Y. Wang, J. Dong, C.-T. He, H. Yin, P. An, K. Zhao, X. Zhang, C. Gao, L. Zhang, J. Lv, J. Wang, J. Zhang, A. M. Khattak, N. A. Khan, Z.

\section{Graphical Abstract}

Chin. J. Catal., 2021, 42: 637-647 doi: 10.1016/S1872-2067(20)63686-5

Iron-based binary metal-organic framework nanorods as an efficient catalyst for the oxygen evolution reaction

Chuchu Wu, Xiaoming Zhang, Huanqiao Li, Zhangxun Xia,

Shansheng Yu, Suli Wang*, Gongquan Sun *

Dalian Institute of Chemical Physics, Chinese Academy of Sciences;

University of Chinese Academy of Sciences; Jilin University

The electronic coupling effect induced by the introduction of a second metal into iron-based MOFs significantly enhances their electrocatalytic performance toward the oxygen evolution reaction.

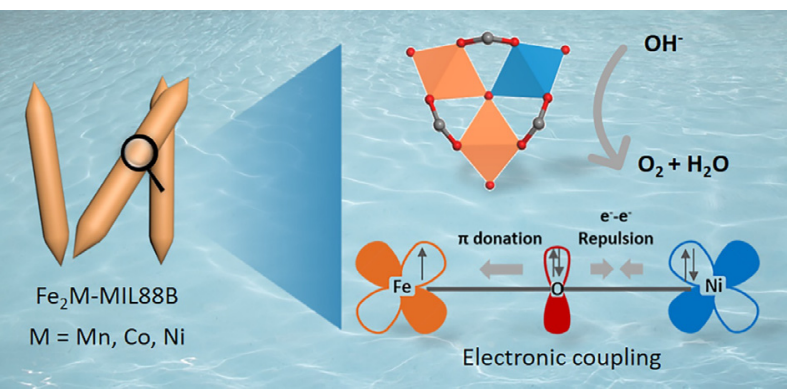


Wei, J. Zhang, S. Liu, H. Zhao, Z. Tang, Nat. Energy, 2016, 1, 16184.

[27] J. Duan, S. Chen, C. Zhao, Nat. Commun., 2017, 8, 15341.

[28] X.-F. Lu, P.-Q. Liao, J.-W. Wang, J.-X. Wu, X.-W. Chen, C.-T. He, J.-P. Zhang, G.-R. Li, X.-M. Chen, J. Am. Chem. Soc., 2016, 138, 8336-8339.

[29] J.-Q. Shen, P.-Q. Liao, D.-D. Zhou, C.-T. He, J.-X. Wu, W.-X. Zhang, J.-P. Zhang, X.-M. Chen, J. Am. Chem. Soc., 2017, 139, 1778-1781.

[30] L. Zhao, B. Dong, S. Li, L. Zhou, L. Lai, Z. Wang, S. Zhao, M. Han, K. Gao, M. Lu, X. Xie, B. Chen, Z. Liu, X. Wang, H. Zhang, H. Li, J. Liu, H. Zhang, X. Huang, W. Huang, ACS Nano, 2017, 11, 5800-5807.

[31] J. Huang, Y. Li, R.-K. Huang, C.-T. He, L. Gong, Q. Hu, L. Wang, Y.-T. Xu, X.-Y. Tian, S.-Y. Liu, Z.-M. Ye, F. Wang, D.-D. Zhou, W.-X. Zhang, J.-P. Zhang, Angew. Chem. Int. Ed., 2018, 57, 4632-4636.

[32] W. Zhou, D.-D. Huang, Y.-P. Wu, J. Zhao, T. Wu, J. Zhang, D.-S. Li, C. Sun, P. Feng, X. Bu, Angew. Chem., Int. Ed., 2019, 58, 4227-4231.

[33] X. Zhang, A. Chen, M. Zhong, Z. Zhang, X. Zhang, Z. Zhou, X.-H. Bu, Electrochem. Energy Rev., 2019, 2, 29-104.

[34] A. J. Howarth, Y. Liu, P. Li, Z. Li, T. C. Wang, J. T. Hupp, O. K. Farha, Nat. Rev. Mater., 2016, 1, 15018.

[35] S. Surble, C. Serre, C. Mellot-Draznieks, F. Millange, G. Ferey, Chem. Commun., 2006, 284-286.

[36] C. Serre, C. Mellot-Draznieks, S. Surblé, N. Audebrand, Y. Filinchuk, G. Férey, Science, 2007, 315, 1828-1831.

[37] X. L. Wang, L. Z. Dong, M. Qiao, Y. J. Tang, J. Liu, Y. Li, S. L. Li, J. X. Su, Y. Q. Lan, Angew. Chem., Int. Ed., 2018, 57, 9660-9664.

[38] Y. Gu, D. Xie, Y. Wang, W. Qin, H. Zhang, G. Wang, Y. Zhang, H. Zhao, Chem. Eng. J., 2019, 357, 579-588.

[39] B. Delley, J. Chem. Phys., 2000, 113, 7756-7764.

[40] S. Grimme, J. Comput. Chem., 2006, 27, 1787-1799.

[41] J. P. Perdew, K. Burke, M. Ernzerhof, Phys. Rev. Lett., 1996, 77, 3865-3868.

[42] B. Delley, J. Chem. Phys., 1990, 92, 508-517.

[43] S. Choi, W. Cha, H. Ji, D. Kim, H. J. Lee, M. Oh, Nanoscale, 2016, 8, 16743-16751.

[44] G.-T. Vuong, M.-H. Pham, T.-O. Do, CrystEngComm, 2013, 15, 9694-9703.

[45] W. Cho, S. Park, M. Oh, Chem. Commun., 2011, 47, 4138-4140.

[46] C. Scherb, A. Schödel, T. Bein, Angew. Chem. Int. Ed., 2008, 47, 5777-5779.

[47] J. Li, W. Huang, M. Wang, S. Xi, J. Meng, K. Zhao, J. Jin, W. Xu, Z. Wang, X. Liu, Q. Chen, L. Xu, X. Liao, Y. Jiang, K. A. Owusu, B. Jiang,
C. Chen, D. Fan, L. Zhou, L. Mai, ACS Energy Lett., 2019, 4, 285-292.

[48] F. Sun, G. Wang, Y. Ding, C. Wang, B. Yuan, Y. Lin, Adv. Energy Mater., 2018, 8, 1800584.

[49] B. Iqbal, M. Saleem, S. N. Arshad, J. Rashid, N. Hussain, M. Zaheer, Chem.-Eur. J., 2019, 25, 10490-10498.

[50] K. Rui, G. Zhao, Y. Chen, Y. Lin, Q. Zhou, J. Chen, J. Zhu, W. Sun, W. Huang, S. Dou, Adv. Funct. Mater., 2018, 28, 1801554.

[51] L. Wang, Y. Wu, R. Cao, L. Ren, M. Chen, X. Feng, J. Zhou, B. Wang, ACS Appl. Mater. Interfaces, 2016, 8, 16736-16743.

[52] C. C. L. McCrory, S. Jung, J. C. Peters, T. F. Jaramillo, J. Am. Chem. Soc., 2013, 135, 16977-16987.

[53] L. Giordano, B. Han, M. Risch, W. T. Hong, R. R. Rao, K. A. Stoerzinger, Y. Shao-Horn, Catal. Today, 2016, 262, 2-10.

[54] B. Han, A. Grimaud, L. Giordano, W. T. Hong, O. Diaz-Morales, L. Yueh-Lin, J. Hwang, N. Charles, K. A. Stoerzinger, W. Yang, M. T. M. Koper, Y. Shao-Horn, J. Phys. Chem. C, 2018, 122, 8445-8454.

[55] A. Grimaud, O. Diaz-Morales, B. Han, W. T. Hong, Y.-L. Lee, L. Giordano, K. A. Stoerzinger, M. T. M. Koper, Y. Shao-Horn, Nat. Chem., 2017, 9, 457-465.

[56] M. Görlin, J. Ferreira de Araújo, H. Schmies, D. Bernsmeier, S. Dresp, M. Gliech, Z. Jusys, P. Chernev, R. Kraehnert, H. Dau, P. Strasser, J. Am. Chem. Soc., 2017, 139, 2070-2082.

[57] S. Lee, K. Banjac, M. Lingenfelder, X. Hu, Angew. Chem., Int. Ed., 2019, 58, 10295-10299.

[58] O. Diaz-Morales, D. Ferrus-Suspedra, M. T. M. Koper, Chem. Sci,, 2016, 7, 2639-2645.

[59] V. Di Castro, G. Polzonetti, J. Electron Spectrosc. Relat. Phenom., 1989, 48, 117-123.

[60] C.-C. Huang, N.-H. Khu, C.-S. Yeh, Biomaterials, 2010, 31, 4073-4078.

[61] S. Ardizzone, C. L. Bianchi, D. Tirelli, Colloids Surf. A, 1998, 134, 305-312.

[62] Z. Cai, D. Zhou, M. Wang, S.-M. Bak, Y. Wu, Z. Wu, Y. Tian, X. Xiong, Y. Li, W. Liu, S. Siahrostami, Y. Kuang, X.-Q. Yang, H. Duan, Z. Feng, H. Wang, X. Sun, Angew. Chem., Int. Ed., 2018, 57, 9392-9396.

[63] Q. Zhou, Y. Chen, G. Zhao, Y. Lin, Z. Yu, X. Xu, X. Wang, H. K. Liu, W. Sun, S. X. Dou, ACS Catal., 2018, 8, 5382-5390.

[64] A. P. Grosvenor, B. A. Kobe, M. C. Biesinger, N. S. McIntyre, Surf. Interface Anal., 2004, 36, 1564-1574.

[65] L. Zhuang, L. Ge, H. Liu, Z. Jiang, Y. Jia, Z. Li, D. Yang, R. K. Hocking, M. Li, L. Zhang, X. Wang, X. Yao, Z. Zhu, Angew. Chem., Int. Ed., 2019, 58, 13565-13572.

\section{具有高效析氧催化性能的铁基双元金属有机框架纳米棒研究

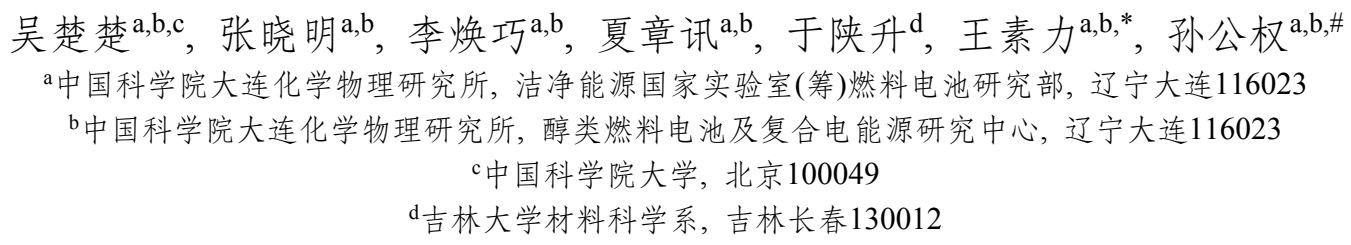

摘要: 析氧反应(OER)是电解水制氢的关键步骤, 开发高效、稳定、廉价的OER电催化剂是目前该领域的研究热点. 碱性电 解液中的OER电催化剂成分以 Mn、Fe、Co、Ni等为主, 其中单一组分的Fe基化合物催化活性不高, 但碱性电解液中的痕量 铁杂质极易掺入 $\mathrm{Ni} 、 \mathrm{Co}$ 等非 $\mathrm{Fe}$ 基材料的结构中, 极大影响其OER催化性能, 即现有大部分非 $\mathrm{Fe}$ 基化合物无法回避 $\mathrm{Fe}$ 的影响. 为探究 $\mathrm{Fe}$ 基多金属电催化剂的活性规律, 本文以结构清晰、组分可控的 $\mathrm{Fe}$ 基金属有机框架材料为基底, 通过掺入 $\mathrm{Mn} 、 \mathrm{Co}$ 、 $\mathrm{Ni}$ 等元素构建双元金属化合物 $\mathrm{Fe}_{2} \mathrm{M}-\mathrm{MIL}-88 \mathrm{~B}(\mathrm{M}=\mathrm{Mn}, \mathrm{Co}, \mathrm{Ni})$, 并围绕上述 $\mathrm{Fe}$ 基双金属电催化剂的构效关系展开研究.

扫描电镜、透射电镜、X射线衍射光谱、红外光谱等表征结果表明, 所制备的 $F e$ 基双金属材料均为具有MIL-88B构型 的纳米棒, 其特征三核金属簇 $\mathrm{Fe}_{3} \mathrm{O}$ 中的一个铁原子被第二元金属所替代, 从而形成相应的三核混合金属簇 $\mathrm{Fe}_{2} \mathrm{MO}$. 上述 $\mathrm{Fe}$ 
基双金属催化剂的析氧催化活性顺序为: $\mathrm{Fe}_{2} \mathrm{Ni}>\mathrm{Fe}_{2} \mathrm{Co}>\mathrm{Fe}_{2} \mathrm{Mn}>\mathrm{Fe}$ (0.1 M KOH电解液). 其中, $\mathrm{Fe}_{2} \mathrm{Ni}-\mathrm{MIL}-88 \mathrm{~B}$ 电催化剂 在 $10 \mathrm{~mA} \mathrm{~cm}{ }^{-2}$ 析氧电流对应的过电位仅需 $307 \mathrm{mV}$, 明显低于OER基准电催化剂 $20 \mathrm{wt} \% \mathrm{Ir} / \mathrm{C}(376 \mathrm{mV})$.

结合材料的元素组成、电化学活性比表面积(ECSA)及金属价态分析发现, 第二元金属的引入会在不同程度上降低Fe 的价态, 其中 $\mathrm{Ni}$ 的影响程度最大, Co次之, $\mathrm{Mn}$ 的影响最小. 借助分子轨道理论对上述实验现象进行了解释. 处于低自旋态 的 $\mathrm{Ni}^{2+}$ 与邻近桥氧 $\mathrm{O}^{2-}$ 之间存在电子排斥作用, 因此部分电子将从 $\mathrm{Ni}^{2+}$ 经 $\mathrm{O}^{2-}$ 转移至高自旋态的 $\mathrm{Fe}^{3+}$, 从而在 $\mathrm{Ni}^{2+}$ 和 $\mathrm{Fe}^{3+}$ 之间形 成了较强的电子耦合作用. $\mathrm{Co}^{2+}$ 具有和 $\mathrm{Ni}^{2+}$ 相似的构型, 但影响稍小. 而 $\mathrm{Mn}^{2+}$ 和 $\mathrm{Fe}^{3+}$ 同为高自旋态, 对 $\mathrm{Fe}^{3+}$ 的电子结构影响 最小, 导致活性改善程度最低. 密度泛函理论计算得到的自旋态变化情况印证了上述推测. 该系列 $\mathrm{Fe}$ 基双金属材料的催化 性能主要受金属活性位点的电子结构影响, $\mathrm{Fe}$ 与邻近金属间形成的电子耦合作用修饰了金属活性位点的电子结构, 从而提 高了材料的OER本征催化活性.

关键词: 析氧反应; 金属有机框架; 电催化; 电子耦合作用; 水氧化

收稿日期: 2020-05-17. 接受日期: 2020-06-23. 上网日期: 2020-09-05.

*通讯联系人.电话/传真: (0411)84762570; 电子信箱: suliwang@dicp.ac.cn

\#通讯联系人. 电话/传真: (0411)84379063; 电子信箱: gqsun@dicp.ac.cn

基金来源：中国科学院战略先导专项(XDA21090300), 国家自然科学基金(91834301), 大连化物所科研创新基金项目(DICP ZZBS201705).

本文的电子版全文由Elsevier出版社在ScienceDirect上出版(http://www.sciencedirect.com/science/journal/18722067). 